\title{
PENGARUH PENDIDIKAN KESEHATAN TERHADAP PENINGKATAN PENGETAHUAN UNTUK MENGATASI KETIDAKNYAMANAN PADA IBU PRIMIGRAVIDA TRIWULAN I
}

\author{
The Effect Of Health Education To Increasing Knowledge To Overcoming \\ Inconvenience To Mother Primigravida $1^{\text {st }}$ Quarterly
}

\author{
Ni Putu Mirah Yunita Udayani ${ }^{1}$, Pande Putu Novi Ekajayanti ${ }^{2}$, Ayu Mayda Dwijayanti ${ }^{3}$ \\ ${ }^{1,2}$ Dosen DIII Kebidanan STIKES Bina Usada Bali \\ ${ }^{3}$ Mahasiswa DIII Kebidanan STIKES Bina Usada Bali \\ Korespondensi: mirahudayani@yahoo.com
}

\begin{abstract}
ABSTRAK
Ketidaknyamanan merupakan suatu perasaan yang kurang ataupun yang tidak menyenangkan bagi kondisi fisik ataupun mental pada ibu hamil. Salah satu upaya untuk mengatasi masalah Ketidaknyamanan tersebut dengan melakukan pendidikan kesehatan kepada Ibu hamil. Tujuan penelitian ini yaitu untuk mengetahui adanya Pengaruh Pendidikan Kesehatan Ketidaknyamanan TW I Terhadap Peningkatan Pengetahuan Ibu Untuk Mengatasi Ketidaknyamanan Pada Ibu Primigravida TW I Di Bps Ni Ketut Suriyanti, S. ST. Penelitian ini dengan rancangan Pra Eksperimen One Group Pre Test Post Test. Teknik sampling yang digunakan adalah total sampling dengan melibatkan sebanyak 30 responden. Penelitian ini dilaksanakan pada tanggal 3 April - 25 Mei. Instrument yang digunakan dalam penelitian ini adalah kuesioner. Hasil penelitian yang diperoleh dengan menggunakan uji wilcoxon yakni nilai $\mathrm{Z}$ sebesar $-4,021$ dengan $\mathrm{p}$ value 0,000 , dengan menggunakan tingkat kepercayaan $(\alpha)=0,05$. Nilai $\mathrm{p}$ value $0.000<\alpha=0,05$, sehingga Ho di tolak, Ha diterima artinya ada pengaruh pendidikan kesehatan terhadap peningkatan pengetahuan untuk mengatasi ketidaknyamanan pada ibu primigravida TW I Di Bps Ni Ketut Suriyanti, S. ST.
\end{abstract}

Kata Kunci: Ketidaknyamanan, pendidikan kesehatan, pengetahuan

\begin{abstract}
It is a feeling of discomfort or an unpleasant lack of physical or mental condition in pregnant women. One effort to address the issue with the inconvenience of doing health education to pregnant women. The purpose of this study is to determine the influence of health education to increase the discomfort the first quarter of maternal knowledge to overcome discomfort in the first quarter of primigravida mothers in midwives in private practice Ni Ketut Suriyanti, S. ST. This research used pre experiment one group pre test post test design. Total Sampling is used in this research with 30 respondents. This reasearch held in April $3^{\text {th }}-$ May 25 ${ }^{\text {th }}, 2012$. Quetioner is used in this research as an instrument. The research result by using Wilcoxon theory is $Z$ value -4.021 with $p$ value 0.000 , by using the significance level $(\alpha)=0.05$. 0000 value of $p$ value $<\alpha=0.05$, so Ho denied, Ha received or in other words, there are influence of health education of maternal knowledge to overcome discomfort in the first quarter of primigravida mothers in midwives in private practice Ni Ketut Suriyanti, S. ST.
\end{abstract}

Keywords: Discomfort, health education, knowledge 
Ni Putu Mirah Yunita Udayani: Pengaruh Pendidikan Kesehatan Terhadap Peningkatan Pengetahuan Untuk Mengatasi Ketidaknyamanan Pada Ibu Primigravida Triwulan I

\section{Pendahuluan}

Kehamilan pertama merupakan pengalaman baru yang dapat menjadi faktor yang menimbulkan stres bagi suami istri. Beberapa stressor ada yang dapat diduga dan ada yang tidak dapat diduga atau tidak terantisipasi misalnya komplikasi persalinan. Selama kunjungan antenatal, ibu mungkin mengeluhkan bahwa ibu mengalami ketidaknyamanan. Kebanyakan dari keluhan ini adalah ketidaknyamanan yang normal dan merupakan bagian dari perubahan yang terjadi pada tubuh ibu selama kehamilan. Beberapa macam ketidaknyamanan pada masa kehamilan TW I, yaitu sering buang air kecil, ngidam, mual - mual, muntah, keputihan, pusing, kelelahan. Dimana keluhan ini adalah hal yang wajar dan tidak perlu dikhawatirkan, hanya saja mungkin mengganggu kenyamanan ibu. Salah satu cara untuk meningkatkan kesadaran ibu hamil tentang ketidaknyamanan TW I adalah dengan meningkatkan pengetahuan ibu primigravida tentang ketidaknyamanan TW I. Setiap orang memiliki respons yang berbeda terhadap diagnosis kehamilan. Bagi sebagian wanita mungkin timbul perasaan gembira yang sangat dengan kehamilan yang sudah direncanakan, tetapi bagi sebagian lainnya yang belum siap, kehamilan dapat menjadi peristiwa yang mengejutkan dan bahkan menimbulkan keputusasaan karena mendengar berita tersebut dan membayangkan masalah sosial serta finansial yang harus ditanggungnya. Essensi promosi kesehatan adalah upaya untuk membuat daya sehingga mampu memelihara dan meningkatkan kesehatan sendiri. Untuk itu perlu dilakukan upaya untuk merubah, menumbuh atau mengembangkan prilaku positif hal ini merupakan bidang garapan utama pendidikan kesehatan (Depkes, 2002).

Menurut hasil studi pendahuluan di BPS Ni Ketut Suriyanti, S. ST Penatih, Denpasar Timur dengan menggunakan teknik/ metode wawancara, didapatkan data bahwa dari $15 \mathrm{ibu}$ primigravida yang memeriksakan kehamilannya diperoleh $60 \%$ (9 orang) ibu primigravida kurang mengetahui tentang pengertian ketidaknyamanan, macam - macam ketidaknyamanan, penyebab ketidaknyamanan yang dialami ibu dan cara mengatasi ketidaknyamanan yang dialami ibu terutama ibu primigravida TW I. Tetapi hanya 40\% (6 orang) ibu primigravida yang mengetahui tentang ketidaknyamanan TW I sebatas macam - macam ketidaknyamanan yang dialami ibu selama hamil dan cara mengatasinya yang diperoleh dari sumber internet dan buku KIA. Berdasarkan tersebut, penulis tertarik untuk melakukan penelitian tentang Pengaruh pendidikan kesehatan terhadap peningkatan pengetahuan untuk mengatasi ketidaknyamanan pada ibu primigravida TW I di Bidan Praktik Swasta Ni Ketut Suriyanti, S. ST.

\section{Tujuan}

Untuk mengetahui pengaruh pendidikan kesehatan terhadap peningkatan pengetahuan untuk mengatasi ketidaknyamanan pada ibu primigravida TW I di Bidan Praktik Swasta Ni Ketut Suriyanti, S. ST.

\section{Metode}

Penelitian yang digunakan merupakan rancangan Pra Eksperimental dengan Onegroup pre test dan post test design. Pengisian kuesioner dilakukan 2 kali sebelum perlakuan (01) dan Sesudah (02) perlakuan. Perbedaan 01 dan 02 diasumsikan merupakan efek pendidikan kesehatan yang diberikan. Tidak ada kelompok pembanding (control group), melainkan sudah dilakukan penilaian pertama tentang ketidaknyamanan TW I yang memungkinkan peneliti menguji perubahan setelah diberikan pendidikan kesehatan. Pendekatan yang digunakan adalah pendekatan prospektif. Jumlah sampel dalam penelitian ini adalah 30 orang dimana merupakan jumlah seluruh populasi (total sampling) yaitu jumlah ibu hamil primigravida TW I di BPS Ni Ketut Suriyanti, S. ST Penatih, Denpasar Timur.

Cara yang digunakan untuk mendapatkan data yang diperlukan, yaitu menggunakan kuesioner dengan membagikan kuesioner pada ibu primigravida TW I di BPS Ni Ketut Suriyanti, S. ST Penatih, Denpasar Timur, dimana sebelumnya peneliti menjelaskan maksud dan tujuan pengisian kuesioner dan responden telah menyatakan persetujuannya. Pengumpulan data akan dilaksanakan d BPS Ni Ketut Suriyanti, S. ST Penatih, Denpasar Timur sampai kurun waktu yang telah ditentukan. Kuesioner untuk mengidentifikasi Pengaruh Pendidikan Kesehatan Terhadap Peningkatan Pengetahuan Untuk Mengatasi Ketidaknyamanan Pada Ibu TW I terdiri dari 20 item pertanyaan dengan kategori "benar dan salah" dan diberikan skor (1) jika benar atau (0) jika salah. Penelitian ini menggunakan 
Ni Putu Mirah Yunita Udayani: Pengaruh Pendidikan Kesehatan Terhadap Peningkatan Pengetahuan Untuk Mengatasi Ketidaknyamanan Pada Ibu Primigravida Triwulan I

dua jenis analisis Univariat dan Bivariat. Dalam pengujian hipotesis statistik Non parametrik menggunakan Uji Wilcoxon Match Pairs Test. Adapun dengan batas kemaknaan 0,05 ( $\alpha$ 0.05). Dilakukan uji statistik dengan komputer.

\section{Hasil}

Bidan Praktik Swasta merupakan salah satu tempat pelayanan kesehatan yang khususnya ibu dan anak yang dipimpin dan dikelola oleh seorang bidan. BPS ini berlokasi di jalan Padma Gg. Harum no. 1 Penatih, Denpasar Utara. Fasilitas yang tersedia di BPS memiliki 3 ruangan yang meliputi ruang periksa, ruang bersalin, dan ruang nifas. Jenis pelayanan yang diberikan adalah pemeriksaan ibu hamil, pertolongan persalinan, pelayanan $\mathrm{KB}$, (KB suntik, pil, dan IUD), imunisasi, pemeriksaan nifas, konseling (untuk remaja, wanita usia subur, ibu hamil, akseptor $\mathrm{KB}$, wanita dalam masa klimakterium, menopause dan lansia). Jumlah tenaga yang ada di BPS diantaranya 5 orang bidan, 1 orang sebagai pemilik BPS dan 4 orang bidan sebagai asisten bidan dengan pendidikan terakhir DIII Kebidanan.

Pada analisis Univariat didapatkan hasil sebagai berikut : Distribusi responden menurut tingkat pengetahuan sebelum diberikan pendidikan kesehatan terdapat responden dengan tingkat pengetahuan kurang sebanyak 15 orang $(50,0 \%)$, tingkat pengetahuan cukup sebanyak 8 orang $(26,7 \%)$ dan tingkat pengetahuan baik sebanyak 7 orang $(23,3 \%)$.

Distribusi responden menurut tingkat pengetahuan sesudah diberikan pendidikan kesehatan terdapat responden dengan tingkat pengetahuan kurang sebanyak 2 orang $(6,7 \%)$, tingkat pengetahuan cukup sebanyak 10 orang $(33,3 \%)$ dan tingkat pengetahuan baik sebanyak 18 orang $(60.0 \%)$.

Pada analisis Univariat didapatkan hasil sebagai berikut : Distribusi Responden Menurut Tingkat Pengetahuan sebelum dan Sesudah Diberikan Pendidikan Kesehatan Di BPS Ni Ketut Suryanti, S. ST didapatkan bahwa dari hasil uji statistik menggunakan Wilcoxon Match pairs test, dapat dijelaskan bahwa nilai $p$ value sebesar 0,000 lebih kecil dari $\alpha 0,05$, maka Ho ditolak atau hipotesis dalam penelitian ini diterima yaitu ada pengaruh pendidikan kesehatan terhadap peningkatan pengetahuan pada ibu hamil Primigravida TW I tentang ketidaknyamanan
TW I di BPS Ni Ketut Suryanti, S. ST Denpasar Timur.

\section{Pembahasan}

Dari penelitian yang telah dilakukan diperoleh tingkat pengetahuan ibu hamil TW I sebelum diberikan pendidikan kesehatan sebagai berikut, responden dengan tingkat pengetahuan kurang sebanyak 15 orang $(50 \%)$, kategori cukup sebanyak 8 orang $(26,6 \%)$ dan kategori baik sebanyak 7 orang $(23,3 \%)$. Hal ini berarti sebagian besar responden di BPS Ni Ketut Suriyanti S. ST sebelum diberikan penyuluhan memiliki tingkat pengetahuan kurang. Hal ini disebabkan karena kurangnya sumber informasi tentang sadari dan minimnya rasa ingin tahu responden mengenai ketidaknyamanan yang dialami ibu primigravida TW I. Sehingga responden belum memahami manfaat yang positif dari pengetahuan yang dimiliki. Perubahan pengetahuan tidak selalu menyebabkan perubahan perilaku, namun hubungan positif antara variabel pengetahuan tertentu tenang kesehatan penting sebelum suatu tindakan pribadi terjadi.

Hasil penelitian selanjutnya setelah diberikan pendidikan kesehatan diperoleh responden dengan tingkat pengetahuan baik sebanyak 18 orang $(60,0 \%)$, kategori cukup sebanyak 10 orang $(33,3 \%)$ dan kategori kurang sebanyak 2 orang $(6,67 \%)$. Hal ini berarti sebagian besar responden di BPS Ni Ketut Suriyanti S. ST memiliki tingkat pengetahuan kategori baik. Tindakan pendidikan kesehatan merupakan suatu metode efektif di dalam meningkatkan tingkat pengetahuan seseorang. Hal ini sesuai dengan teori komunikasi bahwa efektif tidaknya pendidikan kesehatan tergantung pada pencapaian tujuan pemberian pendidian kesehatan itu sendiri. Pada hal ini memiliki tujuan untuk meningkatkan tingkat pengetahuan ibu hamil primigravida TW I tentang Ketidaknyamanan TW I. Pada konteks efektifitas pendidikan kesehatan diukur dari sejauh mana perubahan rata - rata pengetahuan responden sebelum dan sesudah pemberian penyuluhan.

Dari hasil penelitian pengaruh pendidikan kesehatan terhadap peningkatan pengetahuan ibu primigravida TW I tentang Ketidaknyamanan TW I di BPS Ni Ketut Suryanti, S. ST dengan menggunakan uji Wilcoxon Match Pair test terhadap 30 reponden didapatkan nilai $\mathrm{p}$ value $0,000<\alpha=$ 
Ni Putu Mirah Yunita Udayani: Pengaruh Pendidikan Kesehatan Terhadap Peningkatan Pengetahuan Untuk Mengatasi Ketidaknyamanan Pada Ibu Primigravida Triwulan I

0,05, maka hipotesa yang dibuat "terdapat perbedaan tingkat pengetahuan ibu hamil primigravida TW I tentang Ketidaknyamanan TW I sebelum dan sesudah diberikan pendidikan kesehatan".

\section{Kesimpulan}

Berdasarkan hasil penelitian dan pembahasan yang telah disesuaikan dengan tujuan penelitian "Pengaruh Pendidikan Kesehatan Terhadap Peningkatan Pengetahuan Untuk Mengatasi Ketidaknyamanan Pada Ibu Primigravida TW I Di Bps Ni Ketut Suriyanti, S. ST" dapat disimpulkan bahwa sebelum diberikan pendidikan kesehatan, sebagian besar responden memiliki pengetahuan yang kurang mengenai ketidaknyamanan TW I yaitu sebanyak 15 orang $(50.0 \%)$.

Setelah diberikan pendidikan kesehatan, sebagian besar responden memiliki pengetahuan baik yaitu sebanyak 18 orang $(60,0 \%)$. Sehingga dapat dikatakan terjadi peningkatan pengetahuan ibu hamil primigravida TW I tentang ketidaknyamanan TW I dari proses pendidikan kesehatan yang telah dilakukan. Hal ini dipertegas dengan pengujian statistik Wilcoxon Match Pairs test, didapatkan bahwa nilai $p$ value sebesar 0,000 lebih kecil dari $\alpha=0,05$, maka Ho ditolak maka hal ini membuktikan bahwa pendidikan kesehatan berpengaruh dalam meningkatkan pengetahuan ibu hamil tentang Ketidaknyamanan TW I yang khususnya ibu primigravida.

\section{Daftar Pustaka}

Arikunto, S. 2002. Pengantar Metode Penelitian. Jakarta: RinekaCipta

Arikunto, S. 2006. Prosedur Penelitian Suatu Pendekatan Praktek Edisi I Revisi IV. Jakarta : PT Rineka Cipta.

Candra, B. 2008. Metodelogi Penelitian Kesehatan. Jakarta: EGC

Depkes RI. 2002. Modul Safe Mother Hood . Jakarta : FKMUIEndjun, Judi Januadi. 2002. Mempersiapkan Kehamilan Sehat. Jakarta : Puspa Swara.

Endjun, Judi Januadi. 2002. Mempersiapkan Kehamilan Sehat. Jakarta : Puspa Swara.

Fitriani, S. 2011. Promosi Kesehatan Edisi Pertama. Yogyakarta : Maximus.
Grahacendikia. 2010. Jurnal. Desember, 2011. from http://www.materiPengaruhPendidikanKesehatanTerhadapPengetahu anIbuPrimigravidatentangcaraPenanganan KetidaknyamananpadaKehamilanTrimest erBREFERENSIPENELITIANSkripsiTes is.html

Hani, Ummi. 2011. Asuhan Kebidanan Pada Kehamilan Fisiologis. Jakarta: Salemba Medika

Hidayat. 2007. Metode Penelitian Keperawatan Dan Teknik Analisa Data. Jakarta : Salemba Medika

Luhulima, A.S. 2007. Bahan Ajar Untuk Hak Perempuan. Jakarta : Yayasan Obor Indonesia

Machfoedz, dkk. 2007. Pendidikan Kesehatan Bagian dari Promosi Kesehatan.

Mandriwati. 2011. Asuhan Kebidanan Antenatal. Jakarta : EGC

Mubarak, dkk. 2007. Promosi Kesehatan Sebuah Pengantar Proses Belajar Mengajar Dalam Pendidikan. Yogyakarta: Graha Ilmu.

Nanny Lia Dewi, Vivian. 2011. Asuhan Kehamilan Untuk Kebidanan. Jakarta: Salemba Medika

Notoatmodjo, S. 2003. Pendidikan dan Perilaku Kesehatan, Edisi Revisi. Jakarta : Rineka Cipta

Notoatmodjo, S. 2005. Metodelogi Penelitian Kesehatan. Jakarta: Rineka Cipta

Notoatmodjo, S. 2007. Metodelogi Penelitian Kesehatan, Edisi Revisi. Jakarta : Rineka Cipta

Notoatmodjo, S. 2010. Metodelogi Penelitian Kesehatan. Jakarta : Rineka Cipta

Parasmu. 2011. 9 Bulan Yang Maha Menakjubkan. Yogyakarta : Pustaka Araska Media Utama.

Prawirohardjo, S. 2008. Ilmu Kebidanan. Jakarta: PT BINA PUSTAKA

Riwidikdo,H. 2008. Statistik Kesehatan. Yogjakarta : Mitra Cendikia

Riyanto, Agus. 2011. Aplikasi Metodelogi Penelitian Kesehatan. Yogyakarta: Nuha Medika

Saifudin, A.B. 2001. Buku Acuan Pelayanan Kesehatan Maternal dan Neonatal. Jakarta : yayasan bina pustaka sarwono prawirohardjo.

Saifudin, A. 2002. Pelayanan Kesehatan Maternal Dan Neonatal. Jakarta : Yayasan Bina Pustaka Sarwono Prawirohardjo. 
Ni Putu Mirah Yunita Udayani: Pengaruh Pendidikan Kesehatan Terhadap Peningkatan Pengetahuan Untuk Mengatasi Ketidaknyamanan Pada Ibu Primigravida Triwulan I

Saryono. 2010. Metodologi Penelitian

Kebidanan DIII, DIV, S1 dan S2.

Yogyakarta : Nuha Medika

Sugiyono. 2010. Statistik Untuk Penelitian.

Bandung: Alfa Beta

Sulivan, Amanda 2009. Panduan Pemeriksaan Antenatal, jakarta : EGC

Sumantri, A. 2011.Metodelogi Penelitian Kesehatan. Jakarta: Prenada Media

Varney, dkk. 2007. Buku Saku Bidan. Jakarta:

EGC 